\title{
Gest jako nośnik intencji i znaczeń - pragmatyczne funkcje korelatu słowno-gestycznego
}

Ludzie działają, odwołując się do znaczeń, jakie mają dla nich elementy świata, w którym żyją. Znaczenia te pochodzą z interakcji, a zatem są ,negocjowalne" - interpretowane i modyfikowane przez ludzi w konkretnych sytuacjach.

Takim założeniom interakcjonizmu symbolicznego $\mathrm{w}$ socjologii bardzo blisko do założeń pragmatyki, zwłaszcza pragmatyki zorientowanej kognitywnie (por. Taylor 2007: 124-125). Przez pragmatykę zorientowaną kognitywnie rozumiem szeroką perspektywę, analizę kontekstualną wypowiedzi (a nie tylko zdania), płynne granice między intencją a znaczeniem, a także (co tu bardzo istotne) - wyjście poza zjawiska czysto językowe (tradycyjnie rozumiane jako werbalne lub słowne), analizę elementów komunikacyjnych towarzyszących mowie, a w szczególności tych, które współtworzą z mową (tzn. wypowiadanymi słowami) to, co (parafrazując Grice’a) jest rozumiane.

\section{Pragmalingwistyka w badaniach niewerbalnych elementów komunikacji międzyludzkiej}

Jedną z nowszych publikacji poświęconych tym zagadnieniom, w której autor explicite posługuje się narzędziami pragmatyki, jest książka Tima Whartona Pragmatics and Non-Verbal Communication (2009)1. Wharton otwiera przestrzeń badań pragmatycznych dla takich zagadnień jak prozodia, mimika i gesty, odwołując się do m.in. do Grice'owskiej opozycji znaczenia naturalnego i konwencjonalnego (meaning $_{\mathrm{N}}-$ meaning $_{\mathrm{NN}}$ ) (1957) oraz teorii relewancji

* Zakład Teorii Komunikacji, Wydział Polonistyki, Uniwersytet Jagielloński, ul. Gołębia 16, 31-007 Kraków.

1 Recenzowana w czasopiśmie Lodz Papers in Pragmatics: Cruz, M. P. 2009. "Pragmatics and Non-Verbal Communication by Tim Wharton", Lodz Papers in Pragmatics 5.2, 293-316; DOI: 10.2478/v10016-009-0016-8. 
Sperbera i Wilson (1986). Rozważa status i właściwości semiotyczne elementów niewerbalnych w odniesieniu do tradycyjnie rozumianych wypowiedzi, a także ich złożone funkcje pragmatyczne. Jeśli jednak chodzi o zakres tych analiz, autor skupia się przede wszystkim na wykrzyknieniach i wtrąceniach (interjections), pozostałe zjawiska jedynie zakorzeniając na gruncie pragmatyki. Stosunkowo niewiele uwagi poświęca fenomenowi, jakim są gesty (to zaledwie pół rozdziału), powołuje się jednak na dwóch najlepszych i najbardziej znanych badaczy tego zagadnienia: Adama Kendona i Davida McNeilla.

Wharton sięga więc po narzędzia pragmatyki i konsekwentnie je stosuje do badania tych elementów wypowiedzi, które nie są przedmiotem rozważań w tradycyjnych ujęciach zorientowanych pragmalingwistycznie. Z kolei ci, którzy swoje prace poświęcają studiom nad elementami niewerbalnymi towarzyszącymi słowom, nie zawsze sięgają po narzędzia pragmatyki tak, jak robi to Wharton. Nie u wszystkich badaczy gestów można dostrzec Whartonowskie rozumienie pragmatyki w odniesieniu do zachowań niewerbalnych, przynajmniej część z nich, używając słowa „pragmatyczny”, rozumie je raczej bardziej potocznie niż w związku z teoriami takimi jak koncepcje Austina, Searle'a, Grice'a czy Sperbera i Wilson. A. Kendon ${ }^{2}$ odróżnia referencjalną (propozycjonalną) treść wyrażaną w gestach od funkcji i pragmatycznych użyć gestów, przez które rozumie przekazywanie informacji o ustosunkowaniu mówiącego do wypowiedzi czy strukturyzowanie dyskursu (por. Kendon 2004: 359).

Próba ujrzenia gestów z perspektywy czysto pragmatycznej (mam na myśli węższe ujęcie z wyraźnym wskazaniem na klasyków tej dziedziny) to w Polsce m.in. prace Ewy Jarmołowicz ${ }^{3}$ : Czynienie rzeczy za pomoca zachowań niewerbalnych nastawionych na interpretacje (2004) czy Niewerbalne elementy aktów mowy (2005). Specyfika tych prac w odniesieniu do gestów polega jednak na tym, że w dużej mierze ich autorzy zajmują się szczególnym typem gestów - emblematami bądź gestami występującym bez słów (lub jakby obok słów); o silnie skonwencjonalizowanych znaczeniach. Jarmołowicz udowadnia, że tego typu gesty mają moc illokucyjną i stanowią istotne elementy aktu mowy. Co więcej, same mogą być „aktami mowy”, tzn. posiadać płaszczyznę lokucyjną, illokucyjną i perlokucyjną. Do emblematów ${ }^{4}$ należą np. takie gesty, jak palec przyłożony do ust (rozumiany jako prośba o ciszę), uniesienie dwóch palców prawej dłoni (stanowiące przysięgę) czy kiwający się palec wskazujący (interpretowany jako groźba lub ostrzeżenie).

2 To jeden z najbardziej znanych badaczy zjawiska gestykulacji.

3 Jarmołowicz-Nowikow należy do prężnie działającego zespołu pod kierownictwem prof. Macieja Karpińskiego na UAM w Poznaniu, który bada gesty z perspektywy semiotyczno-kulturowej.

4 Emblematy najczęściej zastępują frazę słowną, mają stałe skonwencjonalizowane znaczenia, jednak charakterystyczne dla danej kultury. 
O mocy sprawczej zachowań niewerbalnych wielokrotnie wspominał John L. Austin, choć językoznawcy zdają się pomijać milczeniem tę część jego koncepcji. Zarówno Jarmołowicz, jak i Jolanta Antas (por. Antas, Majewska 2006) podkreślają jednak fakt, że pominięcie przy interpretacji elementów niewerbalnych towarzyszących wypowiedzi może prowadzić do mylnych interpretacji zamiarów nadawcy.

Przykład 1. ilustruje taką sytuację.

Uczestniczka telewizyjnego programu publicystycznego ${ }^{5}$ zwróciła się do swojego oponenta, mówiąc: „Proszę powiedzieć to tym osobom, które żyją poniżej granicy ubóstwa". Rozmówcy byli oponentami, ale zrównanymi w społecznych i konwersacyjnych rolach, które tu (w programie) pełnili. Słowa te zostały wypowiedziane podniesionym głosem i towarzyszył im uwidoczniony na ilustracjach gest palca wskazującego, który skierowany był w dół i ku interlokutorowi, a ręka $\mathrm{w}$ takim ułożeniu kilkukrotnie poruszała się poziomo w kierunku odbiorcy. Wyrażona bezpośrednio w słowach (na płaszczyźnie lokucyjnej) prośba była w istocie nakazem, a nośnikami takiej intencji były elementy zachowaniowe pozawerbalne.

\section{Przykład 1}

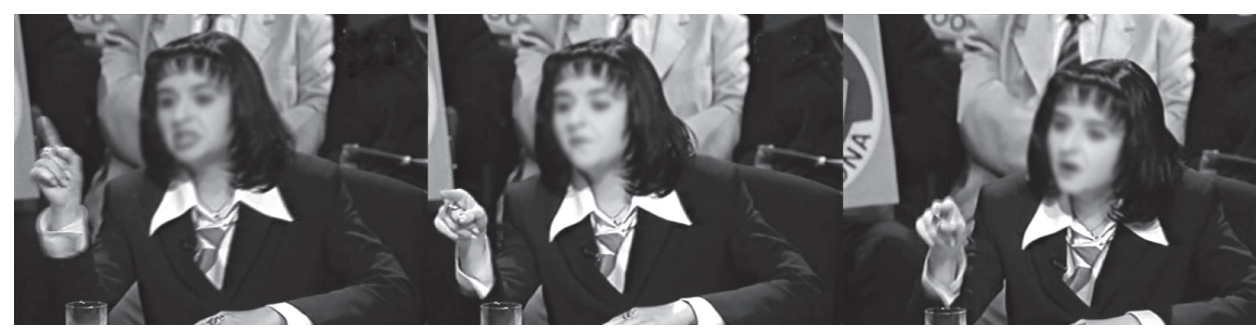

Antas i Majewska piszą, że o tym, z jakim aktem mowy mamy do czynienia, „decydują warunki pragmatyczne wypowiedzi, a zatem także czynniki pozajęzykowe - parajęzykowe i niewerbalne, które towarzyszą temu aktowi, a właściwie konstytuują jego intencjonalność", zaś odbiorca (w danym zdarzeniu komunikacyjnym), poprzez swoje działania werbalne i niewerbalne, w ostateczności może

5 Wszystkie przykłady są cytatami i pochodzą z własnej bazy danych, gromadzonej na potrzeby badań naukowych w Zakładzie Teorii Komunikacji Wydziału Polonistyki UJ. Pozyskiwane są z wyselekcjonowanych materiałów telewizyjnych. Żaden z podanych tu przykładów nie jest odosobnionym przypadkiem dobranym w celu zilustrowania przyjętej tezy. Faktycznie, założeniem moim jest jedynie zobrazować przykładami prawidłowości, o których piszę, jednak wszystkie wykorzystane przykłady są wycinkiem szerokiej bazy materiałowej. Każdy z fragmentów filmowych (z ponad $2000 \mathrm{w}$ bazie) jest ze swej natury komunikacyjnej niepowtarzalny - odnaleźć można jednak pewne wzorce, tendencje czy prawidłowości, w kategoriach których da się opisać zależności między tokiem słownym i pozasłownym. 
być weryfikatorem rzeczywiście przesłanych intencji, zawartych w skierowanym do niego komunikacie (Antas, Majewska 2006: 55-56). Stąd możliwa reakcja interlokutora, który słysząc: „Taka polityka jak wasza doprowadzi do katastrofy ekonomicznej" i widząc towarzyszący tym słowom gest kiwającego się palca wskazującego skierowanego w górę, ripostował: „Ja proszę pana, pana gróźb się nie boję". W tym przypadku gest nie tyle zmienia intencję wypowiedzi, ile ją wyraża i uwypukla; jak piszą Antas i Majewska - „konstytuuje intencjonalność”.

Jarmołowicz słusznie postulowała w jednym $\mathrm{z}$ artykułów, żeby mówić o illokucji komunikatu, a nie illokucji wypowiedzi (przez co mylnie przypisuje się realizację intencji komunikacyjnych nadawcy tylko sferze werbalnej) (2004: 71). Klarowność terminologiczna zapewne jest tu pożądana, choć, jak sama autorka zauważyła (odnosząc się do propozycji Kneblewskiego, aby zamiast aktu mowy używać określenia bardziej realnego, jakim jest akt komunikowania), „,rozwiązaniem problemu nie są wszelkiego rodzaju zmiany terminologiczne, a raczej rozumienie aktu mowy zgodnie z założeniem J. L. Austina" (2005: 96).

\section{Pragmatyczny status zachowań niewerbalnych}

W słynnej pracy (którą uważa się za kamień milowy dla teorii komunikacji, a którą przywłaszczyli sobie psychologowie, choć główny autor był językoznawcą ${ }^{6}$, czyli w Pragmatics of Human Communication (1967) Paul Watzlawick, Janet Beavin i Don Jackson dowodzili, że w sytuacji kontaktu interpersonalnego każde zachowanie jest komunikatem ('nie można nie komunikować'), a poziomy propozycjonalne i kontekstualne (content i attitiude) są przekazywane zarówno digitalnie, jak i analogowo. Digitalność oznacza tu symboliczność i konwencjonalność, a analogowość - ikoniczność 7 . Podejście takie kładzie nacisk na wielokanałowość przekazu (stąd mowa o orkiestralnym modelu komunikacji, por. Winkin (2007)), a także na skutki komunikacji, aktywną postawę interlokutorów i negocjowalność znaczeń.

6 Zwraca na ten fakt uwagę współautorka książki: The fact that Dr. Watzlawick was a linguist (not a psychologist) is highly relevant to his authorship of a book on communication, which drew on his scholarly background and continuing interest in language. Cytat pochodzi z dokumentu opublikowanego na stronie internetowej Janet Beavin Bavelas: "Errors, anachronisms, and faint praise: The 2011 Foreword to the paperback edition of Watzlawick, Beavin Bavelas, and Jackson's Pragmatics of human communication." A study of interactional patterns, pathologies, and paradoxes (1967), http://web.uvic.ca/psyc/bavelas/ New\%20informa tion $\% 20 \% 20$ Pragmatics\%20 of $\% 20$ Human $\% 20$ Communication $\% 20$ - $\% 20$ errors $\% 20$ in $\% 20$ Foreword $\% 20$ to $\% 20$ paperback $\% 20$ \%28July\%202011\%29\%20.pdf [dostęp 17.12.2012].

7 Podział na informacje przekazywane analogowo i digitalnie dziś wydaje się zbyt upraszczający i nazbyt ogólny, zwłaszcza jeśli wziąć pod uwagę ponad kilkunastoletnie badania nad ikonicznością języka, prowadzone w ramach językoznawstwa kognitywnego, a także ustalenia dotyczące poziomów skonwencjonalizowania i arbitralności znaków niewerbalnych. 
W podobnym duchu w swojej pracy wypowiada się wspomniany wyżej Wharton. Intencjonalna komunikacja ludzka jest przez niego rozumiana szeroko, a także głęboko filozoficznie. Intencje są stanami naszego umysłu, które jako ludzie potrafimy przekazywać innym. Intencjonalność jest tu więc odróżniona od wolicjonalności, co ma niebagatelne znaczenie przy określaniu pragmatycznego wymiaru komunikatów niewerbalnych. Jedno z podstawowych pytań, które nasuwa się podczas tych rozważań, dotyczy świadomości podmiotu, który wytwarza zachowania-znaki. Wharton, podobnie jak Watzlawick, Beavin i Jackson, nie ogranicza znaków do dobrowolnie, świadomie i wolicjonalnie nadawanych komunikatów.

W pewnego rodzaju pansemiotycznym spojrzeniu Whartona widać jednak dążenie do wyznaczenia granic czy raczej do metodologicznej jasności względem statusu zachowań niewerbalnych. Granice te może zarysować odpowiedź na pytanie: jaki status pragmatyczny mają poszczególne zachowania - zarówno werbalne, jak i niewerbalne.

Wharton stoi na stanowisku, że to, iż dane zachowanie nie jest wytwarzane (produkowane) celowo (deliberately), nie oznacza, że nie może być celowo uwidocznione (shown) (2009: 32). Innymi słowy, naturalne, spontaniczne, niewolicjonalne zachowania mogą być elementem jawnej, intencjonalnej komunikacji. $\mathrm{Z}$ taką sytuacją mamy do czynienia w przykładzie 2 .

\section{Przykład 2}

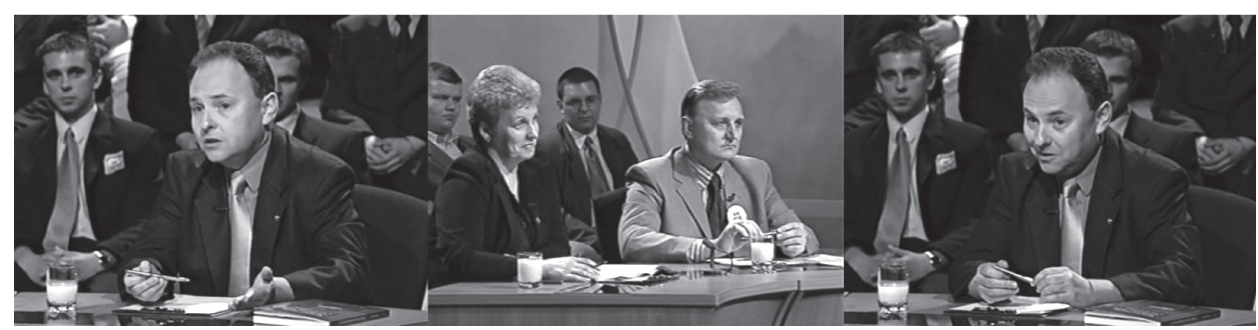

„myśmy wynegocjowali warunki takie, które dają nam narzędzia oczywiście do kontroli/ tego, aby tej ziemi nie sprzedawać, zwłaszcza jeśli ... /pani posel, pani trochę patrzy ironicznie"

Siedzący naprzeciw siebie interlokutorzy są jednymi z kilku uczestników programu telewizyjnego, w którym zabierają głos. Jeden z interlokutorów podczas swojej wypowiedzi zauważa reakcję uczestniczki, przerywa swoją wypowiedź w pół zdania i odnosi się do zauważonej reakcji, mówiąc: „pani poseł, pani patrzy trochę ironicznie". Trzeba dodać, że skomentowane zostało tu zachowanie mimiczne (jedynie niewerbalne) uczestniczki tej sytuacji komunikacyjnej. Przytoczone słowa komentujące reakcję mimiczną świadczą nie tylko o tym, że w procesie komunikacyjnym na równi z zachowaniami werbalnymi zauważane są przez interlokutorów także zachowania niewerbalne. Świadczą też o tym, że te niewerbalne są brane pod uwagę jako komunikacyjnie znaczące -jeśli nawet 
nie wolicjonalne, to jednak ukazywane intencjonalnie (manifestujące się) $)$. Ktoś, kto je „wytwarza” i czyni widocznymi, musi zdawać sobie sprawę z tego, że będąc uczestnikiem sytuacji komunikacyjnej, jest słuchany i obserwowany przez innych uczestników i nie robi nic, aby powstrzymać się przed ujawnianiem tych zachowań. W większości przypadków ludzie nie komentują zachowań niewerbalnych partnerów interakcji, co nie oznacza, że ich nie zauważają lub nie biorą pod uwagę. Są one znaczące dla odbiorców i jako takie są komunikatami, które pragmatycznie oddziałują w procesie komunikowania.

Wharton, opisując pragmatyczny status zachowań niewerbalnych, odwołuje się do teorii relewancji Sperbera i Wilson, w myśl której ludzki system poznawczy jest ewolucyjnie ukierunkowany na poszukiwanie relewantnych informacji - wyzwalających pozytywne efekty poznawcze przy najmniejszym wysiłku poznawczym możliwym do osiągnięcia tych efektów. Sperber i Wilson wielokrotnie zaznaczają, że bodźce w procesie komunikacyjnym nie muszą mieć charakteru językowego, jednak kluczowa jest ich ostensywność. Tym samym wprowadzają na scenę rozważań także zachowania niewerbalne.

Pomimo różnic i otwartych dyskusji autorów teorii relewancji z koncepcjami Grice'a, w zasadzie kooperacji Grice’a (jakon sam podpowiada) zobaczyć można podobne spojrzenie na komunikację . Wszak jest to wersja zasady każącej nam domniemywać o racjonalności ludzkich zachowań. „Jej nieświadome stosowanie powoduje, że nawet $\mathrm{w}$ zetknięciu $\mathrm{z}$ zachowaniami dla nas niejasnymi lub dziwacznymi z góry staramy się je traktować jako sensowne i szukamy ich racjonalnego wyjaśnienia" (Indyk 1992). Po przełożeniu tego na język komunikacji ostensywno-inferencjalnej można rozumować tak: jeśli ostensywny bodziec będzie wart wysiłku inferencji i w określonym kontekście będzie zawierał gwarancję relewancji (czyli założenie wytworzenia optymalnych efektów poznawczych) - stanie się bodźcem komunikacyjnym.

Kilkudziesięcioletnie badania nad gestami pokazały, że jako zachowania komunikacyjne są bardzo niejednorodną kategorią. Niewątpliwie gesty towarzyszące mowie są częścią wysiłku ekspresji (expressive effort), razem z mową tworzą zintegrowany przekaz. Badacze spierają się jednak co do ich właściwości komunikacyjnych, tzn. czy nadawca koduje gestyczną informację dla odbiorcy i czy odbiorca tę informację integruje w procesie dekodowania (por. Gullberg, Kita

8 Posługuję się tym terminem za propozycją polskich tłumaczy Relevance Sperbera i Wilson (2011).

9 Nie zgadzam się z interpretacją teorii Grice’a, zawartą w Relewancji. Autorzy piszą: „zasady współpracy i maksymy [...] nadawcy i odbiorcy muszą znać, żeby skutecznie się komunikować”, a „znajomość zasady relewancji jest potrzebna nadawcom i odbiorcom do komunikowania się w stopniu nie większym niż znajomość zasad genetyki jest potrzebna ludziom do rozmnażania się” [2011: 226]. Uważam, że „znajomość” maksym Grice’a i znajomość zasady relewancji ma ten sam charakter: jest nieuświadamianą, ale wykorzystywaną i rozwijaną umiejętnością w obrębie kompetencji komunikacyjnej. 
2009). Problem jednak zdaje się źle postawiony, bo już same sformułowania: kodowanie i dekodowanie, budzą zastrzeżenia. Sperber i Wilson, podważając modele kodowe komunikacji, wyraźnie pokazali, jak stosunkowo nieliczne są przypadki komunikacji oparte na procesie kodowania i dekodowania. W przypadku zachowań niewerbalnych, mamy przeważnie do czynienia z procesem komunikacji ostensywno-inferencjalnej. Tym samym wszelkie eksperymentalne próby sprawdzania kodowalności tych zachowań są metodologicznie wątpliwe.

\section{Współzależności pragmatyczne między trybem werbalnym i niewerbalnym komunikacji}

Liczne badania o charakterze kwantytatywnym pokazują, że liczba gestów wyraźnie maleje, gdy nadawca nie widzi odbiorcy (najczęściej cytowane badania: Cohen 1977; Cohen, Harrison 1973), co świadczyłoby o tym, że są one wyraźnie komunikacyjne - czyli produkowane ze względu na oddziaływanie na odbiorcę. Jednak każdy zapewne widział sytuację (lub sam jej doświadczył), w której rozmawiający przez telefon człowiek gestykuluje. To z kolei świadczyłoby o samowystarczalności gestów, ich intrapersonalnych funkcjach i niezależności względem modyfikacji kontekstualnych. Ciekawą hipotezę na ten temat postawiła Janet Bavelas, która wraz z zespołem zmodyfikowała eksperyment telefoniczny. Badacze wykazali, że rzeczywiście liczba gestów statystycznie znacząco maleje w sytuacji dialogu telefonicznego, ale tylko w porównaniu z sytuacją rozmowy twarzą w twarz. Jeśli zaś porównać ekspresję gestyczną podczas rozmowy telefonicznej z sytuacją rozmowy telefonicznej prowadzonej z automatyczną sekretarką (właściwie podczas nagrywania się na automatyczną sekretarkę), to tu różnica ilościowa też jest bardzo duża, ale na korzyść sytuacji rozmowy telefonicznej z realnym odbiorcą - wykazano całkowity zanik gestów w przypadku nagrań na sekretarkę. Wynik eksperymentu skłonił do postawienia tezy o zasadniczym wpływie odbiorcy na liczba wykonywanych przez nadawcę gestów - jednak to nie tylko obecność odbiorcy w polu widzenia nadawcy, ale jego jakakolwiek (nawet wyobrażona) obecność w mentalnej przestrzeni interakcji wpływa na intensywność gestykulacji nadawcy (Bavelas i in. 2008).

Wiele badań skupionych jest na wykazaniu, czy i w jakim zakresie znaczenia i intencje wyrażone gestycznie (czy szerzej: niewerbalnie), są brane pod uwagę przez odbiorcę w procesach kognitywnych. Między innymi chodzi o eksperymenty z tzw. powtórnym opowiadaniem (re-telling), gdzie zadaniem odbiorców jest raz jeszcze opowiedzieć historię, którą ktoś chwilę wcześniej im relacjonował i część znaczeń wyrażał gestycznie (w koekspresywnych gestach), a część werbalnie. $\mathrm{Z}$ badań tych wynika, że odbiorca postrzega i włącza w proces komunikacyjno-kognitywny gestykulację nadawcy (McNeill i in. 1994; Cassell i in. 1999), a w szczególności - że podczas konstruowania mentalnej reprezentacji tego, co jest 
mu komunikowane, bierze pod uwagę semantyczną zależność między tokiem słownym i koekspresywanymi gestami (Cassell i in. 1999: 28). Wykazano też, że w powtórnym opowiadaniu historii percypowane uprzednio informacje wyrażone jedynie gestycznie nie są po prostu odtwarzane gestycznie (co mogłoby sugerować jakiś rodzaj gestycznej pamięci krótkotrwałej i niezależne przetwarzanie trybów słownego i gestycznego), ale treści te (np. kierunek poruszania się obiektu) wyrażane są słowami. Pokazuje to, że dla systemu poznawczego gesty i słowa stanowią równie dobre bodźce semantyczne, tzn. w procesie rozumienia traktowane są jako komunikacyjnie relewantne, a odbiorca nie oddziela sztucznie trybu gestycznego od słownego. Podobne wyniki uzyskała Goldin-Meadow (2005), badając komunikację dzieci. Eksperymenty tego typu pokazują, że nawet w przypadku niespójności semantycznej między trybem werbalnym i gestycznym (mismatches, np. nadawca gestem pokazuje „nisko”, a mówi „wysoko”), po pierwsze, często gest wyraża prawdziwy stan wiedzy nadawcy na dany temat (a słowa z różnych względów zostają , dobrane” nieadekwatnie); po drugie, odbiorcy również w takich przypadkach biorą pod uwagę znaczenia wyrażane w gestach, nawet jeśli te znaczenia są konkurencyjne względem znaczeń wyrażanych słowami.

O tym, że zachowania niewerbalne są niezbywalnymi elementami procesu komunikacyjnego może zaświadczać także zjawisko tzw. mimikry ruchowej, którą w wielu swoich pracach opisywała Janet Bavelas (motor mimicry, np. Bavelas $\mathrm{i}$ in. 1986). Jest to rodzaj mimetyzmu komunikacyjnego, przejawiającego się tym, że zachowanie obserwatora podobne jest do tego, które przejawia (lub mógłby przejawiać) obserwowany w danej sytuacji komunikacyjnej. Zachowanie partnera komunikacji (obserwatora, odbiorcy, interlokutora) wygląda jak naśladowanie mimiki, gestów, postawy ciała czy tonu głosu innego uczestnika sytuacji komunikacyjnej. Tak właśnie stało się w opisanym niżej zdarzeniu (przykład 3).

\section{Przyklad 3}

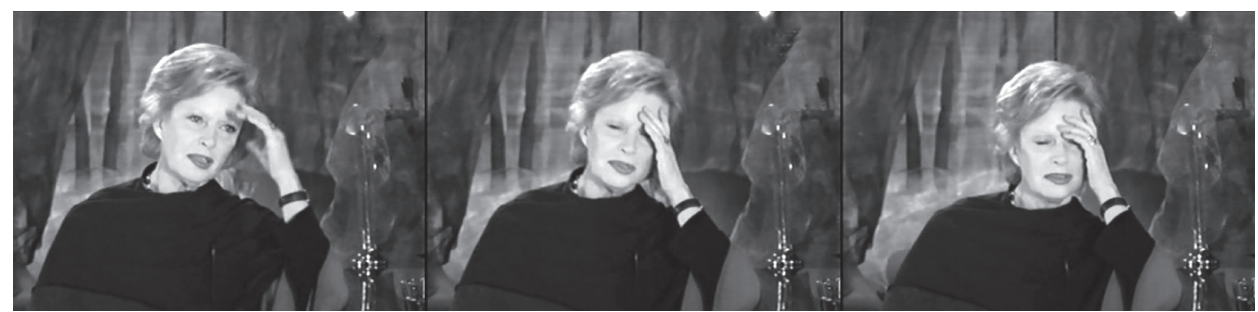

- ,[...] gdzie ci Amerykanie w tych letnich mundurach ze złotymi guzikami wyglądają jak....” - „no jak na amerykańskim filmie”

W programie dwie uczestniczki: dziennikarka i aktorka, rozmawiają o wydarzeniach z życia aktorki. Ta opowiada o wydanym na amerykańskim lotniskowcu przyjęciu, w którym brała udział. Mówi: „,...] gdzie ci Amerykanie w tych letnich 
mundurach ze złotymi guzikami wyglądają jak....” i w tym momencie wykonuje gest (zobrazowany na zdjęciach powyżej; lewa ręka uniesiona do czoła, dotyka go, po czym głowa opada na nią, aktorka przymyka oczy, wzdycha i dwukrotnie w tej pozycji porusza głową przecząco). Bardzo ciekawa jest tu koegzystencja tego zachowania $\mathrm{z}$ frazą, którą mówiąca uprzednio wypowiada. Wypowiedź zostaje przerwana, nie zostaje dokończona po wykonaniu ruchu. Co więcej - dokończenia takiego nie wymaga, komunikacyjnie wraz z zachowaniem tworzy spójną, semantycznie klarowną i pragmatycznie relewantną całość. Zachowanie jednak nie jest uzupełnieniem frazy słownej, to nie gestyczny ekwiwalent brakującego zakończenia. Trudno właściwie mówić tu o braku. Tylko z perspektywy reguł tekstu pisanego może się wydawać, że czegoś tu brakuje. Język mówiony, jak pisze Warchala, odwołując się do Labova, to raczej ,subsystem o odmiennych i dodatkowych regułach gramatykalizacji” (2003: 105). Zachowanie niewerbalne więc nie jest kontynuacją frazy słownej w sensie strukturyzacyjnego substytutu. Jest raczej ustosunkowaniem mówiącej do swojej wypowiedzi, komentarzem dotyczącym relacjonowanych zdarzeń, intencjonalnym zachowaniem wyrażającym zachwyt, symbolicznym gestem symulującym omdlenie i z pewnością ostensywnym bodźcem relewantnym dla drugiej uczestniczki tego zdarzenia komunikacyjnego. Nie czeka ona na dokończenie rozpoczętej frazy słownej, która takiego zakończenia nie wymaga, bo wraz z zachowaniem niewerbalnym tworzy zintegrowany komunikat, nie tylko pełny, ale także sygnalizujący zmianę (zakończenie) tury konwersacyjnej. Dziennikarka więc, nie naruszając żadnych reguł dotyczących zmiany tur konwersacyjnych, mówi: „no jak na amerykańskim filmie”. Komentarz ten jest jednocześnie propozycją dokończenia frazy słownej oraz interpretacją tego, co się usłyszało. Istotny (choć niestety niemożliwy do oddania w opisie, ani na zdjęciu, a jedynie we fragmencie filmowym) jest sposób wypowiedzenia tych słów, który współgra $\mathrm{z}$ tonem głosu aktorki. Ten korelat słowno-niewerbalny jako odpowiedź jest przykładem pragmatycznie rozumianej empatii kognitywno-komunikacyjnej. Nie tylko bowiem jest znakiem rozumienia intencji mówiącej (tu aktorki), ale także potwierdzeniem rozumienia jej ustosunkowania do relacjonowanych wydarzeń (przez „naśladowanie” efektów parajęzkowych).

\section{Gest i słowo jako dwa różne tryby semiotyczne}

Koegzystencja i koekspresywność zachowań werbalnych i niewerbalnych jest przedmiotem wielu badań, ponieważ wszystko wskazuje na to, że zarówno z punktu widzenia nadawcy, jak i z punktu widzenia odbiorcy są one komunikacyjnie zależne. Niewątpliwie jednak są to dwa różne tryby semiotyczne.

Niejednorodność gestów, które jako kategoria znakowa doczekały się najwięcej uwagi ze strony językoznawców, próbowali uporządkować wspomniani wcześniej Kendon i McNeill. Ten drugi ukuł w 1992 r. termin „kontinuum 
Kendona". Kontinuum jest skalą podobieństwa gestów do języka, a zatem skalą skonwencjonalizowania $\left(\right.$ meaning $_{\mathrm{NN}}$ ), która wyznacza przynależność gestu do danego rodzaju. McNeill raz jeszcze odwołał się do podziału i klasyfikacji Kendona (czyli „kontinnum Kendona”) w Gesture and Thought (2005) pokazując, że gesty różnią się ze względu na cztery aspekty:

1. ze względu na stopień zespolenia $\mathrm{z}$ wypowiedzią $\mathrm{w}$ zdarzeniach komunikacyjnych (od gestykulacji współwystępującej z mową, poprzez emblematy, pantomimę, aż do znaków języka migowego);

2. ze względu na relację do semiotycznych właściwości języka - istnienie jednostek w systemie zorganizowanym hierarchicznie (od gestykulacji, która nie ma takiego charakteru, przez pantomimę, która też poza tradycją kulturową nie jest zorganizowana w system, emblematy, z których pewne wykazują istnienie obligatoryjnych elementów i zasad łączenia, do systemowego języka migowego);

3. ze względu na stopień skonwencjonalizowania (kolejno: gestykulacja, pantomima, emblematy i język migowy);

4. ze względu na charakter semiosis (co zresztą wynika z cech poprzednich):

- gestykulacja (jako globalna i syntetyczna; globalna tzn., że znaczenie poszczególnych „części gestu” jest zdeterminowane przez znaczenie całości i tylko tak może być rozumiane; syntetyczna tzn., że pojedynczy gest zawiera w sobie znaczenia, które w zdaniu musiałby być rozczłonkowane, gest je kumuluje);

- pantomima - globalna i analityczna;

- emblematy - rozczłonkowane na dystynktywne elementy, ale syntetyczne;

- język migowy - jego znaki rozczłonkowane na dystynktywne elementy i analityczne.

Kontinuum Kendona (McNeill 1992, 2005):

- stopień zespolenia z wypowiedzią

\begin{tabular}{lccc} 
GESTYKULACJA & EMBLEMATY & PANTOMIMA & JĘZYK MIGOWY \\
\hline - relacja do semiotyki języka & & \\
GESTYKULACJA & PANTOMIMA & EMBLEMATY & JĘZYK MIGOWY \\
\hline
\end{tabular}

- stopień skonwencjonalizowania

\begin{tabular}{llll} 
GESTYKULACJA & PANTOMIMA & EMBLEMATY & JĘZYK MIGOWY \\
\hline- charakter semiosis & & \\
GESTYKULACJA & PANTOMIMA & EMBLEMATY & JEZZYK MIGOWY \\
\hline
\end{tabular}

Kontinuum to jest jedynie pewną propozycją i w związku z tym ma swoje ograniczenia. Jak słusznie zauważa Wharton (2009), jest oparte, po pierwsze, na badaniu stopnia podobieństwa gestów do trybu językowego (język i jego 
właściwości są tu punktem wyjścia), po drugie służy ukazaniu gestykulacji jako trybu wyrażania, leżącego na przeciwległym do języka biegunie semiotycznym. Co jednak jeszcze ważniejsze, kontinuum zakłada pełną kodowość, konwencjonalność, arbitralność, analityczność i systemowość języka, co znów (tym razem w obrębie fenomenów językowych) jest przecież kwestią skali. Niewątpliwie jednak ukazuje ono nie tylko niejednorodność semiotyczną w obrębie kategorii gestów, ile biegunowo różne cechy gestykulacji w stosunku do trybu werbalnego. Współwystępowanie tych dwóch tak różnych trybów wyrażania jest przyczyną swoistej dialektyki (jak nazywa ją McNeill, 2005), która - przejawiając się w zdarzeniach komunikacyjnych - nie może zostać obojętna dla odbiorców (uczestników) interakcji. Zdaje się więc, że nie można mówić o pojedynczych (czy to werbalnych, czy niewerbalnych) bodźcach ostensywnych, uruchamiających proces komunikacji, ale o złożonych konstruktach semiotycznych, będących nośnikami intencjonalności, wyzwalających komunikacyjne procesy inferencyjne.

W 2008 r. Hostetter i Alibali przedstawiły model gestów jako symulacji działań, odwołując się do wielu neurofizjologicznych badań, między innymi do działania neuronów lustrzanych. Wprowadziły wówczas pojęcie progu powstawania gestów, dając odpowiedź, dlaczego w różnych kontekstach pojawia się różna intensywność gestykulacji (próg powstawania gestów to abstrakcyjna granica lub lepiej powiedzieć moment, w którym w trakcie wypowiedzi musi pojawić się gestykulacja).

Te niezwykle ciekawe badania pokazały, że wysokość progu powstawania gestów jest indywidualna i zmienna, a zależy w danej sytuacji od:

- czynników nerwowych - siły połączenia w mózgu obszaru przedruchowego z ruchowym, która z kolei zależy od indywidualnych różnic genetycznych, rozwojowych, różnic w doświadczeniu,

- czynników poznawczych - czyli bieżącego poziomu zaangażowania systemu poznawczego ${ }^{10}$

\section{- aspektów społecznej sytuacji komunikacyjnej.}

Ten ostatni aspekt jest niezwykle interesujący z punktu widzenia pragmatyki komunikacji. Próg powstawania gestu może być bowiem podnoszony lub obniżany przez mówiącego w zależności od celów komunikacji i potrzeb odbiorców ${ }^{11}$. Ponadto możemy podnosić próg powstawania gestów, gdy uznamy, że w danej sytuacji nadmierne gestykulowanie mogłoby zostać odebrane jako nieuprzejme lub nieprofesjonalne (por. Hostetter, Alibali 2008: 505). Autorki nie mają jednak na myśli wolicjonalności, świadomej, zaplanowanej i kontrolowanej strategii, ale

${ }^{10}$ Każdy człowiek ma ograniczone zasoby poznawcze, które może wykorzystywać w danym czasie. Autorki uważają, że zatrzymywanie pobudzenia nerwowego przed rozprzestrzenieniem się do obszarów motorycznych pochłania więcej zasobów poznawczych niż wyprodukowanie gestu.

${ }^{11}$ Ta teza znajduje potwierdzenie w badaniach dotyczących gestykulacji u nauczycieli. Jak relacjonują autorki, nauczyciele gestykulują więcej, gdy tłumaczą nowe zagadnienia. 
neurokognitywny model pobudzania (uruchamiania) procesu komunikacyjnego. Warto zauważyć, że to model, w którym procesy mózgowe, poznawcze, komunikacyjne i społeczne wzajemnie współdziałają i oddziałują na siebie.

Wydawać by się mogło, że Hostetter i Alibali nie mówią nic ponad to, że na pobudzenie gestykulacyjne mają wpływ czynniki osobnicze, kontekstowe i kulturowo-społeczne. Jeśli jednak zobaczyć ten model w świetle koncepcji Sperbera i Wilson, to potwierdza on badania materiałowe, które pokazują, że gesty (w kontinuum Kendona typ „gestykulacja”) nie powielają tego, co zostało wyrażone w słowach.

Rozważmy przykład 4.

\section{Przykład 4}

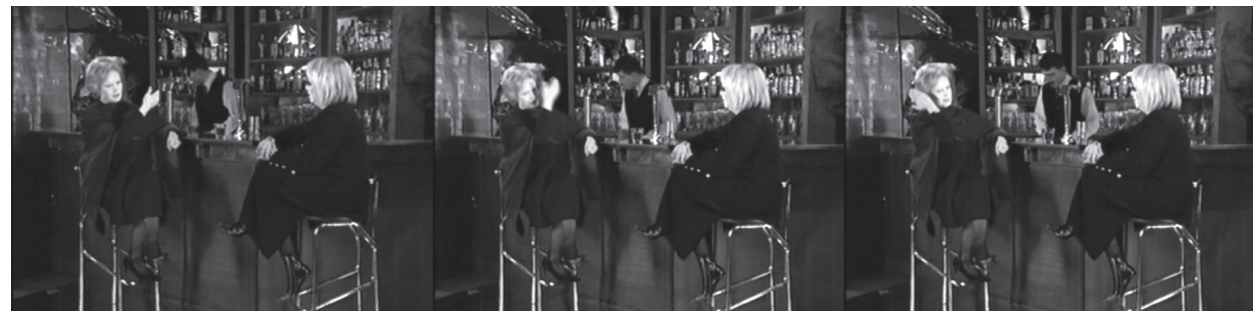

Mówiąca (na fotografiach z lewej strony) opisuje sytuację sprzed wielu lat, kiedy pewna osoba zobaczyła na ulicy chłopca. Narratorka opisując go, mówi: „chłopiec wylizany, jakby go krowa wylizała”. Jednocześnie wykonuje gest prawą ręką, zamaszystym ruchem przesuwając wyprostowaną dłoń z lewej ku prawej stronie na wysokości swojej twarzy (czoła). Gest ten zsynchronizowany jest ze słowem „wylizany” (a także z dalszą frazą ,jakby go krowa wylizała”, bo opisany tu ruch powtarza się). Ta synchronizacja ma swoje uzasadnienie komunikacyjne, gest ten bowiem skorelowany jest semantycznie z predykatem „wylizać, być wylizanym". Jednak fraza werbalna nie jest jednoznaczna - narratorka nie wyraża słowami, że mówiąc „wylizany”, ma na myśli fryzurę chłopca. Owszem, kontekst, w jakim słowa te zostały wypowiedziane - czyli opis wyglądu - interpretację taką mógłby sugerować, jednak nawet w takim przypadku nie ma żadnych podstaw, które pozwalałyby zrozumieć, o jaki konkretnie typ fryzury (,wylizanej”) chodzi ${ }^{12}$. W tej sytuacji komunikacyjnej takie znaczenie wyraża tylko gest. Nie jest to to samo znaczenie, które wyrażone jest słowami, gest nie powiela znaczeń skorelowanej z nim warstwy werbalnej. Można jednak pokusić się o stwierdzenie, że wyraża tę samą intencję, rozumianą jako określony stan umysłu, który komunikowany jest różnymi - dostępnymi i najbardziej efektywnymi - środkami.

${ }^{12}$ Na podstawie samej tylko warstwy werbalnej można by wyobrazić sobie „wylizaną” fryzurę: na dwa boki, prostą grzywkę itp. 
Wracając do modelu Hostetter i Alibali oraz jego związków z teorią Sperbera i Wilson -być może chodzi tu właśnie o efektywność. Skoro, jak piszą Hostetter i Alibali, próg powstawania gestu może być podwyższany i obniżany ze względu na potrzeby komunikacyjne - kluczowa może być ocena komunikującego, co i w jakim stopniu będzie efektywne. A zatem istotny jest punkt widzenia strat kognitywnych mówiącego, ale także punkt widzenia inferującego odbiorcy gwarancja relewancji bodźców. Innymi słowy gesty towarzyszące mowie są relewantne, bo nie powielają znaczeń innych bodźców (słów) - nie powielają znaczeń słów, bo nie byłyby efektywne kognitywnie i komunikacyjnie.

Gestykulacja, przypomnijmy, jest różna od trybu językowego (globalno-syntetyczna w przeciwieństwie do rozczłonkowanego i analitycznego trybu językowego). Różnice te jednak budują - dzięki nim gestykulacja współdziała z językiem, a nie zastępuje go. Gesty nie powielają tego, co zostało wyrażone językowo. Są bodźcami relewantnymi właśnie dlatego, że nie komunikują tego samego, co bodźce językowe. Dla odbiorcy są więc warte wysiłku inferencji, bo mają potencjał wzbudzania pozytywnego efektu poznawczego. Dialektyka gestykulacji i gestów tworzy jednak całość - gesty nie komunikują obok języka, ale wraz z nim.

\section{Podsumowanie}

Współcześni badacze zajmujący się komunikacyjnym znaczeniem gestów (i szerzej - niewerbalnymi zachowaniami komunikacyjnymi) chętnie posługują się terminem multimodal communication ${ }^{13}$, podkreślając tym samym nie tylko wielokanałowość komunikacji, lecz także możliwą i bardzo częstą jednoczesność różnych trybów semiotycznych. Tryby te współdziałają ze sobą na tyle mocno, że wspólnie wyrażają intencje i budują znaczenia, istotne dla interlokutorów. Gesty zespolone kognitywnie (pragmatycznie) z mową nie tylko współtworzą $\mathrm{z}$ językiem znaczenia, ale podobnie jak bodźce językowe $\mathrm{w}$ danym kontekście i danym momencie narracji czy dialogu pełnią kilka funkcji jednocześnie ${ }^{14}$.

Badanie gestów (czy innych znaków niewerbalnych) w kontekście mowy zakłada jednak, niestety, zgłębianie tajemnicy samych tylko gestów, a nie szeroko rozumianej komunikacji międzyludzkiej. To poszukiwanie odpowiedzi na pytania o walory komunikacyjne tylko jednego ze środków komunikowania - gestów

${ }^{13}$ Polskie tłumaczenie tego terminu - komunikacja multimodalna - jest jednak bałamutne, na co zwróciła mi uwagę prof. Jolanta Antas. Zakorzenione w polskiej myśli humanistycznej rozumienie terminu „modalność” rozmija się z angielskim terminem modality. W tym przypadku chodzi bowiem o różnorodność semiotyczną trybów wyrażania.

${ }^{14} \mathrm{~W}$ podobnym duchu wypowiada się sam David McNeill, pisząc o zjawisku layering: „Basically, the term means that single gestures convey content on the discourse and narrative levels simultaneously" (2005: 172). 
- podobnie jak przez wiele dekad tradycyjne językoznawstwo zajmowało się tylko słowem. Kolejnym krokiem ku badaniu pragmatyki komunikacji jest badanie rzeczywistej komunikacji - tzn. wzajemnych związków i oddziaływań wszystkich trybów semiotycznych, które składają się na dane zdarzenie komunikacyjne. W artykule starałam się uwypuklać współzależność kodu werbalnego i niewerbalnego (co stanowi podstawę metodologiczną wszystkich moich dociekań w tym zakresie), jednak ze względu na złożoność tych zjawisk w niektórych przypadkach w opisie na plan pierwszy wysunęły się rozważania na temat elementów niewerbalnych. W każdym jednak przypadku analizie poddawana jest całość komunikatu ze względu na współzależności semantyczne i pragmatyczne. Ukazanie bowiem współdziałania tych trybów (zarówno z perspektywy nadawcy, jak i odbiorcy - choć ta, jak się zdaje, może być istotniejsza) daje nowe możliwości rozumienia, w jaki sposób ludzie komunikują się ze sobą. Nie ma powodu, by sztucznie oddzielać to, co współistnieje, zwłaszcza, że wszystkie dotychczasowe badania pokazują, iż to, co współistnieje, także współdziała. Badanie współdziałania różnych trybów semiotycznych pozwoli na wymodelowanie obrazu rzeczywistych procesów komunikacyjnych porozumiewających się ludzi.

\section{Bibliografia}

Antas, J. 2011. "Gestures - Icons of Thoughts", [w:] E. Jarmołowicz-Nowikow, K. Juszczyk i in. (red.), Gespin - Gesture and Speech in interaction, Poznań, electronic publication: ISBN-9883-926446-5, http://gespin.amu.edu.pl/gespin_old/?q=node/55.

Antas, J., M. Majewska. 2006. W poszukiwaniu jednostki mowy. Metodologiczne refleksje w obliczu nowego rozumienia języka, [w:] W. Chłopicki (red.), Kognitywizm i komunikatywizm - dwa bieguny wspótczesnego językoznawstwa. Dyskusja przy okragłym stole, Kraków: Tertium, 41-57.

Bavelas, J., J. Gerwing et al. "Gesturing on the telephone: Independent effects of dialogue and visibility", Journal of Memory and Language 58, 495-520.

Bavelas, J. B., A. Black et al. 1986. "Experimental methods for studying 'elementary motor mimicry", Journal of Nonverbal Behavior 10, 102-119.

Cassell, J., D. McNeill et al. 1999. "Speech-gesture mismatches: Evidence for one underlying representation of linguistic and nonlinguistic information", Pragmatics and Cognition 7, 1-33.

Cohen, A. A. 1977. "The communicative functions of hand illustrators", Journal of Communication 27, 54-63.

Cohen, A. A., R. P. Harrison. 1973. "Intentionality in the use of hand illustrators in face-to-face communication situations", Journal of Personality and Social Psychology 28, 276-279.

Goldin-Meadow, S., S. M. Wagner. 2005. "How our hands help us learn", Trends in Cognitive Sciences 9, 234-241.

Grice, H. P. 1957. "Meaning”, The Philosophical Review 66.3, 377-388.

Gullberg, M., S. Kita. 2009. "Attention to Speech-Accompanying Gestures: Eye Movements and Information Uptake", Journal od Nonverbal Communication 33, 251-277, DOI 10.1007/ s10919-009-0073-2. 
Hostetter, A. B., M. W. Alibali. 2008. "Visible embodiment: Gestures as simulated action”, Psychonomic Bulletin \& Review 15, 495-514, DOI: 10.3758/PBR.15.3.495.

Indyk, M. 1992. Obszary pragmatyki, [w:] R. Nycz (red.), Po strukturalizmie. Współczesne badania teoretycznoliterackie, Wrocław: Wiedza o kulturze.

Jarmołowicz, E. 2004. Czynienie rzeczy za pomoca zachowań niewerbalnych nastawionych na interpretacje, „Forum Artis Rhetoricae” 1, 59-72.

Jarmołowicz, E. 2005. Niewerbalne elementy aktów mowy, „Investigationes Linguisticae” 12, 89-96.

Kendon, A. 2004. Gesture: Visible Action as Utterance, New York: Cambridge University Press.

McNeill, D. (red.). 2000. Language and gesture, New York: Cambridge University Press.

McNeill, D. 1992. Hand and mind. What Gestures Reveal about Thought, Chicago: The University of Chicago Press.

McNeill, D. 2005. Gesture and Thought, Chicago: The University of Chicago Press.

McNeill, D., J. Cassell, K.-E. McCullough. 1994. "Communicative effects of speech mismatched gestures", Research on Language and Social Interaction 27, 223-237.

Sperber, D., D. Wilson. [1986] 2011. Relewancja. Komunikacja i poznanie, red. M. Jodłowiec, A. Piskorska, Kraków: Tertium.

Taylor, J. R. [2002] 2007. Gramatyka kognitywna, Kraków: Universitas.

Warchala, J. 2003. Kategoria potoczności w języku, Katowice: Wydawnictwo Uniwersytetu Śląskiego.

Watzlawick, P., J. Beavin, D. Jackson. 1967. Pragmatics of Human Communication. A study of interactional patterns, pathologies, and paradoxes, New York: Norton.

Wharton, T. 2009. Pragmatics and Non-Verbal Communication, New York: Cambridge University Press.

Winkin, Y. 2007. Antropologia komunikacji. Od teorii do badań terenowych, Warszawa: Wydawnictwo Uniwersytetu Warszawskiego. 